\title{
ПРОБЛЕМНІ АСПЕКТИ ОПАНУВАННЯ СУЧАСНИМИ АКТОРАМИ ТВОРІВ МАСОВОЇ МУЗИКИ ІНОЗЕМНИМИ МОВАМИ
}

\begin{abstract}
Анотація. У зв’язку з перманентною музично-драматичною природою національного театру, активізацією сучасного культурного полілогу та тенденцією універсалізації актора акцентуеться значимість опанування акторами творів масової музики іноземними мовами. Підкреслено важливість опанування такого репертуару як чинників розширення компетентнісного кола та процесу творчої самоідентифікації та самореалізації актора. Висвітлено особливості таких етапів опанування акторами творів масової музики іноземними мовами, як: когнітивний; фонетичний, артикуляційний; оволодіння інтонаціями мови; оволодіння стилістичними особливостями масової музики; оволодіння вокально-виконавською специфікою естрадного співу при збереженні настанов bel canto; семантико-змістовне опанування вербального тексту; корегування «вокального образу» твору з режисерським задумом, тембровою фрарбою ролі, сценічним завданням.
\end{abstract}

Ключові слова: вокальне мистецтво, вокальне виховання актора, виконавство, творча самоідентифікація, творча самореалізація.

Soboleva Olena

Kharkiv I.P. Kotlyarevsky National Universty of Arts

\section{PROBLEM ASPECTS OF CONTROLLED BY MODERN ACTORS OF WORKS OF MASS MUSIC IN FOREING LANGUAGES}

Summary. The musical-dramatic nature of Ukrainian national theatre, the dynamism of modern cultural polyloque, syntheticity and spectacle as modern theatre`s features and the need to form modern actor`s universal personality determinate the special importance of vocal education of the actor and mass music in foreign languages as part of his vocal repertoire. The relevance of the article is determined by the lack of special intelligence on the mastery of actors in the repertoire of foreign languages, despite the significant increase in researchers' attention to the vocal education of the actor. The purpose of the article is to cover of the actor's work on works of modern music in foreign languages as an important component of self-realization and self-identification of the creative personality. The article emphasizes the importance of mastering works of mass music in foreign languages as a means of forming such significant in the context of modern theatre competencies of the actor as the ability to form a full, creatively comprehended, individually colored artistic image, creative, cultural and linguistic mobility. The specifics of the following snags of mastering the specified repertoire are substantiated and highlighted: cognitive, related the understanding the degree of conformity of the work to the creative personality of the actor, avoiding performance imitation and forming one`s own interpretation; phonetic, articulatory - associated with the performance of "modulation" in another language space; mastering the vocal-performing specifics of pop singing (sound production based on medium (weak) impedance, language position of the singing apparatus, freedom of breathing with the dominant importance of short intonation constrictions) while maintaining the guidelines of bel canto (round, "hidden" sound) and reference; semantic mastery of the verbal text; adjustment of the "vocal image" of the work with the director's idea, the timbre of the role, the stage task.

Keywords: vocal art, vocal education of the actor, performance, creative self-identification, creative selfrealization.

$\Pi^{2}$ остановка проблеми. Виняткова важливість вокальної складової - ознака українського драматичного театру, яка маркуе національну своєрідність його народної та профресійної царин. Саме музично-драматична природа вирізняла славетний театр корифеїв, в якому було відбито сутнісні настанови національного художнього образу світу та стверджено національну ідентичність особистості актора в контексті художньої рефлексіі. Сучасне тяжіння театру до синтетичності та видовищності водночас iз потребою у забезпеченні конкурентоспроможності театральних колективів [8, с. 118] зумовлює зростання вимог до вокального рівня актора та набуття ним високого рівня вокальної майстерності, пов'язаної з опануванням світового спадку музичної культури. Опанування акторами сучасного вокального репертуару, необхідне за умов активізації виходу національного театру на міжнародну арену, актуалізуе питання щодо осмислення осо- бливостей роботи актора над вокальними творами, зокрема іноземними мовами, затребуваними у процесі самореалізацї творчої особистості.

Проте процес формування вокальної компоненти творчої особистості сучасного актора ускладнюють не тільки акцентовані дослідниками часта відсутність музичної освіти, вокальних навичок (дихання. звуковидобування, звуковедення), спотворене уявлення щодо специфіки власного тембру й діапазону тощо [7, с. 9], фрактична ідентичність мовного та співацького регістрів [6, с. 337]. Специфічною перешкодою на шляху розширення репертуарних обріїв акторів та формування методичних настанов опанування сучасних вокальних творів, зокрема іноземними мовами та належними до сфери масової музики, стає також домінантна значимість bel canto [6, с. 336], певна перевага творів національного музичного мистецтва та певна вторинність питань оволодіння акторами навичками естрад- 
ного співу в вокально-методичному дискурсі, що зумовлюе актуалізуючий модус даної статті.

Аналіз останніх досліджень і публікацій дозволяє зафріксувати тенденцію значного посилення зацікавленості науковців проблематикою вокального виховання студента-актора. Порушена у працях таких науковців як Г. Бень, Л. Гринь, О. Данільчук, О. Дзюба, В. Дорошенко, О. Єрошенко, С. Сгібнева тощо, вона характеризуеться передусім співвіднесеністю із вокально-методичними настановами академічного вокалу, певною активізацією обгрунтування індивідуально орієнтованого підходу та акцентуацією потреби у формуванні універсальної творчої особистості зокрема на основі стилістично різноманітного репертуару. Проте питання опанування вокального репертуару з царини масової музики іноземними мовами до сьогодні перебуває у статусі периферійного, що складає невирішені раніше частини загальної проблеми й актуалізуе дослідницький вектор статті.

Мета статті - висвітлення найбільш значущих у контексті вокальної підготовки сучасного актора етапів роботи над творами сучасної масової музики іноземними мовами як важливої складової самореалізації та самоідентифікації творчої особистості в умовах динамізації культурного полілогу у часі та просторі.

Виклад основного матеріалу. Напруженість культурного полілогу сучасності не тільки значно проблематизуе питання національної своєрідності культур. Їх різноспрямоване «перетинання» 3 одного боку, а 3 іншого - потужна тенденція міжвидового синтезу видів мистецтва, тяжіння до видовищності надають особливої неоднозначності напрямам і засобам творчої самоідентифікації творчої особистості актора. «Вписуючись» у сучасні обрії художніх пошуків i набуваючи певної універсальності [2, с. 111; 3 , с. $155 ; 6$, с. 335], в деяких випадках вимушено шукаючи самореалізації в “інших» культурних просторах, сучасний актор постає перед необхідністю формування таких винятково актуальних для сучасного актора компетентностей, як:

- здатність до формування повноцінного, творчо осягненого, індивідуально забарвленого художнього образу;

- творча мобільність - готовність до вирішення новаційних художніх завдань та опанування нових навичок і вмінь;

- культурна мобільність - здатність до виявлення творчої рефрлексії в іншому культурному просторі;

- мовна мобільність - здатність до виконавської самореалізації в динамічно змінюваному мовному середовищі за умов глобалізаційного перефрорматування культурного ландшафту, що забезпечує осмислену саморепрезентацію актора як носія культурної пам'яті.

В опануванні репертуару, зокрема належного до царини масової музики, іноземними мовами (зокрема англійською - як фрактично вербальним атрибутом сучасної масової музики) виокремимо ті проблемні етапи - проблемні сорери, які найчастіше виникають у процесі формування вокального «образу» актора.

Зазначимо, що індивідуально-орієнтований підхід і суспільно детермінована потреба універ- салізащії актора передбачає певну свободу студента у виборі навчального репертуару. Проте творчо осягненому й індивідуально інтерпретованому виконанню творів сучасної масової музики іноземними мовами акторами, особливо студентами-акторами, для яких вони часто є більш ніж притяжними в силу їх популярності, часто перешкоджає їх позначеність певним «виконавським локусом». Виконавська, зокрема й артикуляційна, своерідність, темброва барва голосів співаків, репертуар яких складають опановувані студентами твори, спонукають майбутніх акторів до певного наслідування виконавських маркерів у силу їх популярності та закріпленості в статусі рейтингових у широких слухацьких колах на перцептуальному рівні.

Першим, когнітивним етапом роботи над таким репертуаром слід визнати попередне формування власної інтерпретації творів, яка передбачає наявність таких сформованих здатностей, як:

- осягнення студентом відповідності обраного твору власним естетичним пріоритетам як маркерам творчої особистості [10];

- осягнення відповідності обраного студентом твору його вокальним здібностям, фрактурі та амплуа;

- уникання від стереотипного відтворення виконавського дублювання- наслідування твору; - інтелектуально детерміноване, творчо осмислене створення його нової версії, «вкладеної» в обрії власної творчої особистості.

Значущим $є$ етап виконавської «модулящії» в інший мовний простір. Відмінності фонетики англійської мови потребують відмови від фррикативного «г», точної артикулящії альвеолярних звуків, виразного проте «неакцентуйованого» вимовляння дифртонгів і специфічних шиплячих, специфрічної «нейтральності» певних голосних, осмисленого та змістовно наповненого подовження / редукції голосних, особливості фрранцузької фонетики виявляються у відсутності оглушення у приголосних, відсутності дифртонгів, значущості назалізації тощо. О. Данильчук, наголошуючи на значущості фонетичного методу у процесі опанування вокальним мистецтвом, у зв'язку із цим акцентує, що «щонайменші зміни устрою артикуляції однієї і тієї ж фонеми створюють зовсім нові акустичні й свого роду аеродинамічні умови для роботи голосових зв'язок, що позначаеться й на тембрі голосу» [5, с. 55]. В. Антонюк, звертаючись до окреслення специфіки фонетики в контексті різних мовних просторів, зазначає, що вона є детермінантом ступеня енергійності мов, визначає висоту «розмовного тону певних голосних звуків, сполучених акустичними чинниками, зосередженими в особливостях артикуляції, динамічному співвідношенні голосних та приголосних, типових послідовностей фонем» [1, с. 84].

За таких умов одним із головних проблемних етапів, які постають у процесі вокального становлення та розвитку актора, видається можливим визначити як вільне оперування фонемами, притаманним іноземним мовам, так і збереження природного тембру співацького голосу актора. Вирішення означеної дуалістичної проблеми вбачається у застосуванні таких засобів творення актором вокального «компоненту» ролі (вокального твору): 
- попередне прослуховування виконання іншими виконавцями (співаками) з акцентуацією уваги на артикуляційних моментах;

- виокремлення фонетично та артикулящійно складних моментів;

- робота перед дзеркалом над відпрацюванням природної артикуляції, естетично офрормленої та відповідної до специфіки національного вимови, водночас із винайденням адекватної тембрової фрарби;

- форомування природного та відповідного до фронетичних особливостей вербального тексту звуковидобування та логіки голосоведення в конкретному творі;

- запис вимовляння вербального тексту з подальшим самоаналізом та груповим аналізом.

Не менш важливим саме для актора стає етап творчого проникнення в мелодику мови, вільного володіння мовними інтонаціями, які дозволяють майбутньому акторові відчути виконавську свободу. Зазначимо, що така свобода стає можливою тільки за умов наявності відпрацьованих навичок співацького дихання, опанування динамічними фрарбами, а також урахування особливостей наголосу. Наприклад, англійська мова вирізняється наявністю двох наголосів у слові, які можуть не збігатися 3 акцентними інтонемами, фрранцузька - чіткістю та швидкістю мовлення та зв’язністю, невідокремленістю слів, нередукованістю голосних, фріксованістю наголосу на останньому складі. Це суттево позначається на специфріці вокального фрразування, яке вимагає від актора виконавської гнучкості, певної творчої толерантності - готовності «переналаштування» раніше відпрацьованих алгоритмів фразування.

Значимість такої виконавської мобільності підвищуеться й у зв'язку зі стилістичними особливостями масової музики, позначеної значущістю ритму як одного 3 головних засобів виразності, повторюваністю ритмонем, певною спонтанністю, імпровізаційною свободою ритмічного малюнку та вторинністю значення квадратних, симетричних побудов тощо.

Іншим проблемним завданням на цьому етапі видаеться можливим окреслити формування навичок відповідного до виконавської стилістики естрадного співу та стилістики масової музики звуковидобування, заснованого на середньому (слабкому) імпедансі, мовній позиції співацького апарату, свободі дихання при домінантній значимості нетривалих інтонащійних побудов. Надважливою при такій виконавській модуляції є опора на базові принципи академічного вокалу, зокрема збереження округлого, певним чином «прикритого» звуку та опорності дихання.

Одним із найскладніших етапів опанування навчального репертуару іноземними мовами можна вважати семантико-змістовне опанування вербального тексту. Складовими такого пізнання є:

- детальний розбір вербального тексту;

- виявлення його ключових семантем;

- осягнення сенсу тексту як художньої цілісності та водночас як невід'ємного компоненту досвіду певної культури та тезаурусу творчої індивідуальності;

- індивідуальне формування художнього образу виконуваного твору.
На цьому етапі опанування акторами вокального репертуару іноземними мовами особливої значимості набувають акцентовані Л. Гринь принцип мотивації навчально-пізнавальної діяльності [4, с. 97] та С. Сгібневою «взаємозвя’зок образно-раціонального та емоційно-образного мислення» [9, с. 253].

Проте особлива багатокомпонентність такого завдання зумовлена саме специфрікою акторської діяльності. О. Дзюба у зв'язку із цим наголошуе, що «одна 3 головних особливостей співу драматичних акторів - прагнення до достовірності сценічного образу» [6, с. 342]. Дійсно, на відміну від власне вокалістів, акторові доводиться вирішувати не тільки проблеми виконавського втілення твору, а й формувати той вокальний образ, який, з одного боку, відповідає режисерському задуму, а 3 іншого - $є$ невід'ємною тембровою фрарбою конкретної сценічної ролі, акторської особистості та амплуа, з третього - відбиває неповторність творчої індивідуальності.

За цих причин опанування репертуару іноземними мовами стає своєрідною синкретичною троїстою творчою проблемою, в якій фронетичний, звукоутворювальний та власне художній аспекти постають як нерозривно пов'язані. У зв'язку 3 інтегративністю творчого завдання, що його вирішуе актор в таких випадках М. Швидків наголошуе, що «опанування технічної та художньої сторони дикції, рівно ж як і дихання та звукоутворення - єдиний творчий процес, який складається однак 3 декількох елементів, а саме: - робота над ясністю та зрозумілістю тексту, який вимовляеться; - співвідношення співочої дикції з літературною розмовністю (орфоепія в співі); - особливості вимови залежно від образу» [11, с. 149].

Саме на цьому етапі роботи над вокальними творами іноземними мовами утворюється своєрідне методичне та виконавсько-проблемне коло, в якому кожен із етапів опанування вербального та музичного шарів постає як невід'емний від попереднього та водночас як запорука успішного, творчо доцільного досягнення переконливого, індивідуально забарвленого та відповідного до творчого амплуа та особистості актора й «драматургічного рельефру» конкретної ролі.

Висновки. Опанування творів масової музики іноземними мовами є складовою процесу самореалізації та самоідентифрікації творчої особистості за умов культурного полілогу та важливою сферою вокального виховання сучасного універсального актора, що в комплексі забезпечує формування значущих у контексті специфіки сучасного театру компетентностей. Як особливо важливі у процесі розширення виконавських, репертуарних обріїв актора окреслюються такі етапи роботи: когнітивний, пов'язаний із осмисленням ступеня відповідності твору творчій особистості актора, униканням виконавського наслідування та формуванням власної інтерпретації; фонетичний, артикулящійний - пов'язаний iз виконавською "модуляцією» в інший мовний простір; оволодіння інтонаціями мови; оволодіння стилістичними особливостями масової музики; оволодіння вокально-виконавською специфікою естрадного співу при збереженні настанов bel canto; семантико-змістовне опанування вербального тексту; співвіднесення - корегування «во- 
кального образу» твору з режисерським задумом, тембровою фрарбою ролі, сценічним завданням.

Перспективи подальших досліджень вбачаються у методичному обгрунтуванні принципів оволодіння акторами, зокрема студентамиакторами, атрибутивними для естрадного співу та масової музики вокальними виконавськими прийомами, які $е$ значущим чинником розширення кола професійних компетентностей та забезпечення акторського універсалізму й конкуретноспроможності сучасного представника театрального мистецтва.

\section{Список літератури:}

1. Антонюк В.Г. Українська вокальна школа: етнокультурологічний аспект. Київ : Українська ідея, 2001.144 с.

2. Бень Г. Особливості співу акторів драми. Вісник Львівського університету. Серія мистецтвознавство. 2012. № 11. C. 111-116.

3. Гринь Л.О. Інтеграція в професійну підготовку майбутнього актора музично-драматичного театру спеціалізації «Сольний спів: академічний та естрадний». Педагогіка фборлування творчої особистості у вищій та загальноосвітній школах. 2013. Вип. 32(85). С. 155-161.

4. Гринь Л.О. Нормативна основа вокальної підготовки актора музично-драматичного театру: система принципів. Вісник Запорізького національного університету. Серія : Педагогічні науки. 2018. № 1(30). С. 95-100.

5. Данильчук О.Я. Актуальність фонетичного методу в процесі виховання співака виконавця. Молодий вчений. 2019. № 10(74). C. 53-56.

6. Дзюба О.А. Специфіка вокальної підготовки драматичних акторів у ВНЗ. Мистецтвознавчі записки. 2017. Вип. 32. С. 334-343.

7. Дорошенко В.О. Сольний спів як засіб виховання студента-актора. Харків : «Колегіум», 2010. 152 с.

8. Срошенко О.В. Особливості вокального навчання низьких чоловічих голосів студентів-акторів (на матеріалі українських класичних музично-драматичних творів). Культура України. 2016. Вип. 54. С. 116-127.

9. Сгібнєва С.С. Роль особистісно-орієнтованого підходу в вокальній творчості драматичного актора. Проблели взаєлодї̈ мистеитва, педагогіки та теорії і практики освіти. 2018. Вип. 51. С. 241-257.

10. Уманець О.В. Естетичні пріоритети особистості як маркери образу людини в контексті культури постсучасності. Філософія в сучасному світі : Матеріали I Міжнародної науково-практичної конференції (20-21 листопада 2020 р., Харків). Харків : Друкарня Мадрид, 2020. С. 262-264.

11. Швидків М.Л. Художня виразність мовлення як основа оволодіння технікою співу. Наукові записки Тернопільського національного педагогічного університет іл. Володимира Гнатюка. Серія : Мистеитвознавство. 2014. № 1. C. 145-150.

\section{References:}

1. Antonyuk V.G. (2001) Ukrayinska vocalna shkola: ethno-culturologichnyi aspect [Ukrainian vocal school: ethnoculturological aspect]. Kyiv: Ukryinska ideya. (in Ukrainian)

2. Ben H. (2012) Osoblyvosti spivu actoriv dramy [Peculiarities of vocalization for drama theatre actors]. Visnyk of the Lviv university. Series Art Studies, 11, pp. 111-116. (in Ukrainian)

3. Grin L.O. (2013) Integratziya v profesiynu pidgotovku maybutnogo actora musichno-dramatychnogo teatru spetzializatziyi «Solnyi spiv: academichnyi ta estradnyi» [Integration in the professional training of future actor musical drama theatre of specialization "Solo singing: academic and pop»]. Pedagogy of creative personality formation in higher and general education schools, vol. 32(85), pp. 155-161. (in Ukrainian)

4. Grin L.O. (2018) Normatyvna osnova vocalnoyi pdgotovky actora muschno-dramatychnogo teatru: systema prynyzypiv [Normative bases of actor vocal training for musical dramatic theatre]. Bulletin Zaporizhzhia National University. Pedagogical Science, vol. 1(30), pp. 95-100. (in Ukrainian)

5. Danyilchuk O.Ya. (2019) Aktualnist phonetychnogo method v protzessi vyhovannya spivaka vykonabtzya [Actuality of the phonetical method in the process of education of the singer]. Young Scientist, vol. 10(74), pp. 53-56. (in Ukrainian)

6. Dziuba O.A. (2017) Spetzifika vocalnoyi pidgotovky dranatychnykh actoriv u VNZ [Specific of the vocal educating theatrical actors in the higher art-schools]. Notes of Art Criticism, vol. 32, pp. 334-343. (in Ukrainian)

7. Doroshenko V.O. (2010) Solnyi spiv yak zasib vykhovannya studenta-actora [Solo singing as a means of educating a student-actor]. Kharkiv: «Colegium». (in Ukrainian)

8. Yeroshenko O.V. (2016) Osoblyvosti vocalnogo navchannya nyzkykh cholovichykh golosiv studentiv-actoriv (na materiali ukrayinskikh clasychnykh musichno-dramatychnykh tvoriv) [Features of the vocal training of deep male voices of students-actors (a case study of the Ukrainian classical musical and drama works)]. Culture of Ukraine, vol. 54, pp. 116-127. (in Ukrainian)

9. Sgibneva S.S. (2018) Rol osobystisno-oriyentovanogo pidkhodu v vocalniy tvorchosti dramatychnogo actora [The role of the person-centered approach in the vocal art of dramatic actor]. Problems of Interaction of Art, Pedagogy and Theory and Practice of education, vol. 51, pp. 241-257. (in Ukrainian)

10. Umanets O.V. (2020) Estetychni priorytety osobystosti yak marker obrazu lyudyny v kontexti cultury postsuchasnosti [Aesthetic priorities of personality as markers of human mage in the context of postmodern culture]. Proceeding of the Philosophy in the modern world (Ukraine, Kharkiv, November 20-21, 2020) (eds.: Tararoyev, Ya.V., Kipensky, A.V., Korablyova, N.S.). Kharkiv: Drukarnya Madrid, pp. 262-264. (in Ukrainian)

11. Shvydkiv M.L. (2014) Khudozhnya vyraznist movlennya yak osnova ovolodinnya tekhnkoyu spivu [Artistic expressiveness of pronunciation as a basis of the capture the technique of singing]. The Scientific Issues of Ternopil Volodymyr Hnatiuk National Pedagogical University. Series: Art Criticism, vol. 1, pp. 145-150. (in Ukrainian) 


\title{
ПЕААГОГІЧНІ НАУКИ
}

DOI: https://doi.org/10.32839/2304-5809/2021-5-93-11

УДК 376.112 .4

Ананко С.А., Запорожченко Т.П.

Національний університет «Чернігівський колегіум» імені Т.Г. Шевченка

\section{ВИКОРИСТАННЯ МЕТОДИКИ «ШІСТЬ ЦЕГЛИНОК» В НОВІЙ УКРАЇНСЬКІЙ ШКОЛІ}

\begin{abstract}
Анотація. Докорінні зміни відбуваються в освітніх закладах України. Важливим аспектом освіти є: розвиток креативності дитини, здатність творчо підходити до розв'язання проблем, легко адаптуватися у будь-якому середовищі. Тому перед закладами освіти стає завдання виховати всебічно розвинену особистість. В статті описується методика «ШІСЬЬ ЦЕГЛИНОК», яка спрямована на розвиток компетентностей учнів початкової школи. Так описуються ігри-завдання, спрямовані на розвиток компетентностей, що необхідні для навчання кожного дня. У статті підкреслюеться така значущість використання методики «шість цеглинок», як те що під час конструювання дитина легко засвоює багато знань, умінь і навичок. «Шість цеглинок» - це ефективність впровадження LEGO-конструктора в НУШ, ігри-завдання з набором iз шести цеглинок LEGO DUPLO певних кольорів (червоного, помаранчевого, жовтого, зеленого, блакитного та синього). Для роботи за цією методикою учні та учитель мають індивідуальні набори 3 шести цеглинок. «Шість цеглинок» - це інструмент та практичний засіб, який реалізовуе ігрові та діяльнісні методи навчання в НУШ.
\end{abstract}

Ключові слова: Нова українська школа, методика «шість цеглинок».

Ananko Svitlana, Zaporozhchenko Tetiana

National University "Chernigov Collegium" named after T.G. Shevchenko

\section{USING THE SIX CELLS METHODOLOGY IN THE NEW UKRAINIAN SCHOOL}

Summary. Roller changes take place in educational institutions of Ukraine. An important aspect of education is: the development of creativity of a child, the ability to creatively approach problems easily adapted in any environment. Therefore, before institutions of education, the task is to educate a comprehensively developed personality. The article describes the method of "six bricks", which is aimed at developing competencies of elementary school students. So describes the objects of tasks aimed at developing competencies that are needed to study every day. The article emphasizes such a significant use of the method of "six bricks" as that during the design of a child easily absorbs a lot of knowledge, skills and skills. "Six bricks" is the effectiveness of the implementation of the LEGO designer in the bush, a task game with a set of six Lego DUPLO bricks of certain colors (red, orange, yellow, green, blue, and blue). To work on this method, students and teacher have individual sets of six bricks. "Six bricks" is a tool and a practical tool that implements gaming and activity methods of learning in the bush. Inclusion in the educational process of the method of "six bricks" is considered one of the important conditions for the formation and children in the new Ukrainian school of cognitive abilities. With the designer, a successful knowledge of knowledge is successful. The article reveals features that develop in schoolchildren when using Lego. By combining the components of the designer, the child learns to fantasize, draw conclusions... Lego helps to instill interest in knowledge, ability to receive them, relying on meaningful and interesting material. The main method of learning with Lego is the principle of "training through the action" - the applicants receive knowledge in the process of modeling models using the designer. This teaches them to analyze their actions, as well as demonstrate the dependence between practice and outcome. Despite the fact that it is created from Lego, it's a pleasure and knowledge. Interaction with the designer makes it possible to relax, develop, receive new knowledge - and all this simultaneously. The thorough analysis of scientific works gave us the opportunity to consider Lego designers - as an interesting, cognitive material that stimulates children's imagination, memory, forms motor skills, ability to interest, show different options for its use. In addition, Lego is not only a designer for young children, and a whole pedagogical system, comics, movies, games, etc.

Keywords: Nova Ukrainskaia school, "six loafs" methodology.

П остановка проблеми. Сьогодні система освіти зазнає суттєвих змін. Перед педагогом стоїть завдання виховати всебічно розвинену особистість. В освітньому процесі з'являеться велика кількість нових ігор та розваг. Серед них велику значущість приділяеться ЛЕГО технологіям, які допомагають краще засвоїти матеріал і спрямовані на краще засвоєння дітьми знань, умінь та навичок.

Аналіз останніх досліджень і публікацій. Історія знаменитого конструктора почина- ється в далекому 1932 році, коли данський столяр Оле Кірк Крістіансен відкрив свій бізнес та виробляв звичайні побутові речі. Оскільки компанія не приносила очікуваного прибутку, згодом він почав виробляти дерев'яні кубики для дітей. Нове підприемство, яке повністю змінило життя молодого бізнесмена, отримало назву LEGO, від данських слів «leg» і «godt», тобто «грати» та «добре». У 1947 році виробництво розширилось, тому в асортименті з'явились пластмасові кубики з ідентичними випуклос- 
тями, які давали змогу їх з'єднати між собою. Хоча така іграшка вже була відомою у Великобританії, Оле змінив їі дизайн, чим приемно здивував публіку. Хоча нові вироби не були такими цупкими, як дерев'яні, вони досить легко з'єднувались між собою. Це і був перший конструктор LEGO.

У 1958 році компанія перейшла до рук сина засновника Готфріда. Він вивів бізнес на міжнародний рівень, створивши цілу іграшкову систему. Саме тоді був запатентований новий дизайн цеглинок, який використовуеться до теперішнього часу. Його особливість в тому, що всі деталі можна з'єднувати між собою, не зважаючи на те, що вироби можуть належати колекціям, випущеним в різні роки.

Виділення не вирішених раніше частин загальної проблеми. На мою думку, мало приділяеться уваги методиці використання ЛЕГО в новій українській школі.

Головна мета ціеї роботи спрямована на те, щоб показати, що ця методика спрямована не тільки на розвиток компетентностей учнів, а й на становлення самого педагога.

Виклад основного матеріалу. Конструктор - це матеріал необхідний для творчої гри дитини, вона відчуває себе творцем. Конструктор дає можливість експериментувати й творити свій власний світ, де нема меж.

Тому включення в освітній процес конструктора, можна вважати однією з важливих умов формування у них загально пізнавальних здібностей, завдяки яким відбувається успішне засвоєння знань.

Також при використанні ЛЕГО розвиваються такі риси:

1) Дрібна моторика. Поєднуючи компоненти конструктора, дитина вчиться робити точні рухи, він відчуває дрібні виступи й кути предметів. Подібна стимуляція робить доброчинний вплив на рухові й мовні зони в корі головного мозку.

2. Допитливість. У процесі складання діти роблять багато пробують рухів, роблять помилки й виправляють їх. Таким чином набори заохочують вільну творчість і бажання експериментувати.

3. Мислення. Конструювання сприяє розвитку пам'яті та аналітичних здібностей, воно вчить дитину виявляти взаємозв'язки між предметами, порівнювати й узагальнювати, дає бачення майбутнього результату.

4. Терпеливість i цілеспрямованість. Конструктор - найкращий засіб в арсеналі педагога, що працюе з гіперактивними дітьми.

5. Робота в колективі. Багато продуктів ЛЕГО розраховані на роботу в класі, гуртку або колективі однолітків, тим самим розвиваючи комунікативні навички.

6. Творчі навички. Граючи в ЛЕГО, дитина може проявляти франтазію, виходити за рамки інструкцій та створювати щось нове. Освоївши базові моделі, він переходить до здійснення власних проєктів.

«Шість цеглинок» - це технологія навчання, яка допомагає учням тренувати пам'ять, розвивати моторику і творчо мислити. Через гру вони зможуть навчитися таких важливих, передбачених новою українською школою умінь, як, наприклад, вирішення проблемних завдань.
Рибаки. Мета діти навчаються грати в команді, розв'язувати проблемні питання, логічно обгрунтовувати свою думку.

Завдання: Спочатку діти обговорюють інфрормащію про рибалку (хто, що знає), використовуючи малюнки, картинки.

Хід гри: діти утворюють команди. Їм пропонують спільно своїми цеглинками створити вудочку. Потім надається час для обговорення стратегій для будування вудочки, щоб зловити рибу. Діти перевіряють вудочки на міцність, ловлячи рибу.

Запитання: завдяки чому риба спіймалась на вашу вудочку? Що буде, якщо вашу вудочку схопить важча риба?

Придумай-домалюй. Мета: діти вчаться творчо мислити, пращювати самостійно та в групі, та вчитися поважати думку інших.

Завдання: Діти вчаться створювати будь-яку фігурі на всякі теми (рослина, тварина, машина...). Далі діти вчать прикладати на аркуш паперу малюнок та обводити його. Вчаться презентувати свої малюнки.

Запитання: що створила ваша команда? Кому і як були розділені ролі?

Побудуй, як зможеш. Мета: за допомогою цього завдання діти вчаться творчо мислити, фантазувати, працювати самостійно.

Завдання: запропонувати дітям об'єднатися або самостійно побудувати споруду та презентувати.

Запитання: Як ви з'єднали цеглинки в одне ціле? Що можна ще побудувати? Як можна описати вашу модель?

Літературні завдання. Мета: вчити дітей розуміти художні твори та розуміти, підкреслювати головну проблему, аналізувати пропонувати свій варіант, викладати думки, знаходити літературні приймання, вміти розкладати твір на основні частини.

Завдання: взяти аркуш паперу певного кольору - це буде скарбничка.

Пригадати твір, який читали. Запропонувати поділити певний твір на частини. Потім запропонувати дітям розкласти: в червону скарбничку - не звичні речі, синьою - головні герої твору, жовту - основну проблему твору, зелену - який варіант вирішення був запропонований автором, блакитну - свій варіант розв'язання проблеми. Спочатку дітям пропонуеться 3 двома кольорами, а потім завдання ускладнюеться.

Запитання: Що цікавого у ваших скарбничка? Що на справді допоможе розв'язувати проблему?

Математичні завдання. Мета: навчити швидко реагувати, закріпити раніше вивчені дії.

Завдання: дітям видають цеглинки на яких зображені цифри від 1 до 3, а також знаки «=», «+», «-». За допомогою цих цифр і знаків дитина складає вирази та записуе їх у зошит.

Запитання: Що складного було? Які вирази викликали складність?

Висновки. Працюючи 3 конструктором ЛЕГО, можна будувати моделі й при цьому навчатися, отримуючи задоволення від гри. Коли придумуєш моделі сам, відчуваєш себе профресійним інженером, механіком, будівельником або великим конструктором. I це здорово! Це дає повну свободу дій. Робота є жвавою і цікавою і відкриває абсолютно нові перспективи, де немає меж франтазії. 
Конструювання сприяе розвитку мислення, спритності, а також інтелекту, уяви та творчих задатків. Сприяе формуванню таких якостей, як уміння концентруватися, здатність співпрацювати з партнером, і найголовніше - почуття впевненості в собі. Якщо з дитинства прагнути до пізнання - це перейде в уміння вчитися конструювання направлено і сприймати нове 3 великим інтересом.

Таким чином, робота з освітніми конструкторами ЛЕГО, дозволяе дітям у формі пізнавальної гри дізнатися багато важливих ідей і розвивае необхідні в подальшому житті навички суспільно активної, творчої особистості, яка самостійно генеруе нові ідеї, приймае нестандартні рішення.

Методичні поради. 1) Необхідно дотримуватись легкого старту тобто давати кожній дитині таку складність завдання, яка відповідае ії рівню складності. Кожну дитину необхідно підтримувати, що б вода прагнула до успіху та йшла вперед.
2) Необхідно бути гнучким. Педагог повинен бути у взаемодії з дітьми, не повинен нав'язувати свої ідеї, свою думку. Необхідно допомагати реалізовувати думки дітей.

3) Необхідно давати час для реалізації задумів.

4) Не наголошувати на кінцевий результат, а необхідно підтримувати той процес, в якому перебуває дитина.

5) Віддавайте перевагу відкритим заняттям. НЕ ІСНУС ЄДИНО ПРАВИЛЬНОЇ ВІДПОВІДІ.

6) Надавати потрібно дитині більше свободи й самостійності. Перепитуйте дитину своє бачення, свої думки.

7) Дитину необхідно більше схвалювати, заохочувати. Завжди пропонуйте дитині зворотний зв'язок. Показуйте свою зацікавленість у дії дитини.

8) Довіряйте можливостям дитини. Не пропонуйте свій варіант, своє бачення, свої результати.

ПАМ'ЯТАЙТЕ! Під час гри буде панувати так званий шум діяльності. Не вимагайте цілковитої тиші, а навпаки заохочуйте їх до спілкування.

\section{Список літератури:}

1. Методичний посібник «ШІСТЬ ЦЕГЛИНОК». URL: https://nus.org.ua/wp-content/uploads/2018/05/tseglinokkviten-2018-web.pdf

2. Конструктори Лего (LEGO), як освітне середовище в початковій школі. URL: https://naurok.com.ua/ vikoristannya-lego--tehnologiy-v-osvitnomu-prostori-novo-ukra-nsko-shkoli-123419.htm

3. Как использовать Лего для изучения математики. URL:http://www/uaua/info/ot-6-do-9/shkola-ot-6-do-9/news48608-kakispolzovat-lego-dlya-izucheniya-matematiki/

4. Гра по-новому, навчання по-іншому : Методичний посібник / Упорядник О. Рома. The LEGO Foundation. 2018. URL: https://mon.gov.ua/storage/app/media/nova-ukrainska-shkola/LEGO/po-novomu-navchannya-po-inshomu.pdf

\section{References:}

1. Methodological guide "STYLE CEGLINKS". URL: https://nus.org.ua/wp-content/uploads/2018/05/tseglinokkviten-2018-web.pdf

2. LEGO Constructors as an Educational Environment in the Primary School. URL: https://naurok.com.ua/ vikoristannya-lego--tehnologiy-v-osvitnomu-prostori-novo-ukra-nsko-shkoli-123419.htm

3. How to use Lego to study mathematics. URL: http://www/uaua/info/ot-6-do-9/shkola-ot-6-do-9/news-48608kakispolzovat-lego-dlya-izucheniya-matematiki/

4. Game in a new way, learning in another way. Methodical guidebook / Instructor O. Roma-The LEGO Foundation. 2018. URL: https://mon.gov.ua/storage/app/media/nova-ukrainska-shkola/LEGO/po-novomu-navchannya-po-inshomu.pdf 